\title{
HOW TO TRAIN EVALUATORS OF ADULT EDUCATION STAFF AT A EUROPEAN LEVEL? TOWARDS THE DESIGN OF A PILOT CURRICULUM IN EDUEVAL PROJECT
}

\author{
Loredana Perla \\ University of Bari Aldo Moro, Italy \\ Viviana Vinci \\ University of Bari Aldo Moro, Italy
}

\begin{abstract}
The evaluation of professionals involved in Adult Education staff has a crucial role in order to guarantee the quality of Adult Education (AE). EduEval is a project of the LLP Grundtvig Programme, coordinated by University of Milano-Bicocca, Italy (http://www.edueval.eu/), established with the main objective of redefining the professional profile of the evaluator of Adult Education staff. In this framework, six partners from five European countries work with a collaborative approach. The project offers a new methodology in the field of AE that arises from the importance of a cooperation between practitioners of the AE staff and academic researchers. The paper focuses on the pilot course designed by University of Bari to create a curriculum for the initial training of the professionals involved in the evaluation of AE staff.
\end{abstract}

Keywords: Adult Education, Collaborative approach, EduEval, Evaluation, Grundtvig, Lifelong Learning, Training.

\section{Introduction}

The evaluation process is strictly connected with the professional development of all professionals involved in the Adult Education staff. EduEval - Evaluation for the Professional Development of Adult Education Staff is an EU project part of the Lifelong Learning Programme Grundtvig Multilateral Project, coordinated by Prof. M.G. Riva, University of MilanoBicocca, Italy (see: http://www.edueval.eu/). The project involves six partners from five different European countries: 1) University of Milano-Bicocca, Italy; 2) Rezeknes Augstskola, Latvia; 3) Wyzsza Szkola Pedagogiczna TWP W Warszawie, Poland; 4) Technological Educational Institute Of Crete, Greece; 5) Universitat Jaume I, Spain; 6) University of Bari „Aldo Moro”, Italy.

EduEval is focused on the evaluation of professionals involved in Adult Education staff (e.g. educators, social workers, trainers) and aims at redefining the professional profile of the evaluator of Adult Education staff within an European framework, in order to guarantee the quality of Adult Education.

EduEval contributes to the promotion of a European culture of evaluation in the Adult Education system and offers a new methodology in the field of AE, based on a collaborative approach that arises from the importance of a cooperation between practitioners of the AE staff and academic researchers. 
An important milestone of the project is represented by a mobility workshop, since it proves to be an occasion to share theories and practices about the evaluation of AE staff, including practitioners and researchers, in order to build up collaborative knowledge (see also a Wiki platform: http://wiki.edueval.eu/index.php/Main_Page).

At the same time, EduEval will draft some Guidelines that can be helpful to both professionals and policy makers of the Adult Education system and a Handbook that will summarize the theoretical background and its practical implications in providing evaluation methods for AE staff.

A curriculum for the initial training of the professionals involved in the evaluation of AE staff is the main output of the project, in order to promote the quality and productivity of those who work in the AE field, preventing and coping with their risk of burn-out and occupational-related diseases.

\section{State of art}

Evaluation is a critical issue for Adult Education policies; in this sense, important investments at an European level ensured high quality of the Adult Education system (Making a European Area of Lifelong Learning a Reality, EC, 2001; Adult learning: It is never too late to learn, 2006, EC). Adult education may intervene in many fields, involving different categories of people. Several professional profiles working in the Adult Education field are: teachers, trainers, coaches, mentors, tutors, administrative personnel, human resource managers, quality managers, directors, coordinators, consultants, certification organization personnel, psychologists, sociologists, cultural mediators, anthropologists, educationalists, volunteers. Adult Education represents an interdisciplinary field of education. In recent years, in the light of a growing political and scientific interest for the education of employed adults, there is an emerging research area that can be included into the field of Curriculum studies with a particular focus on the training of Eda Staff evaluators. The aim is to standardise gradually the varied set of monitoring and evaluation activities (not always endorsed by scientific communities) of professionals involved in social education. These activities need both a theoretical design and a practical implementation. In this framework. ECETIS project - European Competencies Evaluation Training Integrated Scheme (2011-1-FR1-LEO05-24457) distinguishes two types of skills in the evaluator's professional profile: core competencies and specific competencies. Core competencies (or transverse) include a set of transferable competencies evaluators should possess to implement the assessment.

Specific competencies are additional skills, knowledge and attitudes that may be required to perform specific tasks. They are strictly connected with the work environment and a specific function within a professional area or role. 
Table 1. Core competencies and specific to the generic role of evaluator

\begin{tabular}{|l|l|}
\hline \multicolumn{2}{|l|}{ Core Competencies } \\
\hline Competencies & Units of Competency \\
\hline $\begin{array}{l}\text { Professional } \\
\text { development and } \\
\text { improvement }\end{array}$ & $\begin{array}{l}\text { Demonstrate awareness of him/her own capacity and limitations } \\
\text { To be engaged for the continuous improvement of its own knowledge } \\
\text { and skills and of the service } \\
\text { Integrate theory into practice in evaluation process }\end{array}$ \\
\hline $\begin{array}{l}\text { Information } \\
\text { management }\end{array}$ & $\begin{array}{l}\text { Knowledge of updated information on evaluation procedure and } \\
\text { accreditation schemes } \\
\text { Use ICT (tic) for evaluation purposes }\end{array}$ \\
\hline $\begin{array}{l}\text { Interaction } \\
\text { effectiveness }\end{array}$ & $\begin{array}{l}\text { Establish appropriate working relationships with all the persons } \\
\text { involved in the evaluation process, internal and external of the } \\
\text { organization } \\
\text { Ability to communicate effectively with colleagues or clients, using } \\
\text { the appropriate level of language }\end{array}$ \\
\hline $\begin{array}{l}\text { Coordination } \\
\text { teams }\end{array}$ & $\begin{array}{l}\text { Skills to cooperate and coordinate effectively in a team of } \\
\text { professionals } \\
\text { Networking and leadership development }\end{array}$ \\
\hline $\begin{array}{l}\text { Comply with } \\
\text { ethical } \\
\text { guidelines }\end{array}$ & $\begin{array}{l}\text { Demonstrate appropriate ethical behavior and professional conduct in } \\
\text { the fulfillment of roles and responsibilities } \\
\text { Demonstrate sensitiveness and awareness of clients cultural } \\
\text { differences to interact effectively with all populations }\end{array}$ \\
\hline
\end{tabular}

Table 2. Core competencies and specific to the generic role of evaluator

\begin{tabular}{|c|c|c|c|}
\hline \multicolumn{4}{|c|}{ Specific competencies } \\
\hline Functions & Competencies & Units of Competency & Contents \\
\hline $\begin{array}{l}\text { 1. Planning the } \\
\text { process of } \\
\text { professional } \\
\text { performance, } \\
\text { skills and } \\
\text { evidence of } \\
\text { skills that will } \\
\text { receive } \\
\text { recognition and } \\
\text { accreditation }\end{array}$ & $\begin{array}{l}\text { Identification of the } \\
\text { professional profile } \\
\text { to evaluate } \\
\text { Planning the } \\
\text { assessment process } \\
\text { according to the } \\
\text { professional field } \\
\text { or workplace of } \\
\text { candidate } \\
\text { Advising the } \\
\text { candidate for the } \\
\text { evaluation process } \\
\text { of professional } \\
\text { competence to } \\
\text { which he is } \\
\text { observing } \\
\text { Participation in } \\
\text { coordinated } \\
\text { evaluation of } \\
\text { professional skills }\end{array}$ & $\begin{array}{l}\text { Designing the assessment of } \\
\text { professional competence in a } \\
\text { particular professional profile } \\
\text { Collect and determine the } \\
\text { regulations that determine the } \\
\text { adequacy of the profile } \\
\text { Set the units of competency } \\
\text { for which to obtain evidence } \\
\text { Concrete assessment } \\
\text { activities according to the } \\
\text { method suitable for obtaining } \\
\text { of new evidence } \\
\text { Identify and organize the } \\
\text { activity to be performed by } \\
\text { the candidate in accordance } \\
\text { with the provisions of } \\
\text { proposed evidence. } \\
\text { Organize initial briefings with } \\
\text { candidates according to the } \\
\text { established evaluation plan. }\end{array}$ & $\begin{array}{l}\text { 1. Context of the } \\
\text { assessment } \\
\text { process and } \\
\text { accreditation of } \\
\text { professional } \\
\text { competence } \\
\text { 2. The procedure } \\
\text { of evaluation and } \\
\text { accreditation of } \\
\text { competencies }\end{array}$ \\
\hline
\end{tabular}


CAPIVAL project - Capitalizing on Validpack: going Europe wide (511883-LLP-1-2010-RO-KA4-KA4MP) is a KA4 - Dissemination and Exploitation of Results project of the EU Lifelong Learning Programme. It aims to exploit the results of VINEPAC project - Validation of informal and nonformal psycho-pedagogical competencies of adult educators (www.vinepac.eu), especially the use of the Validpack instrument that facilitates the documentation and evaluation of trainer's competences acquired in formal, non-formal or informal learning contexts. Validpack consists of a set of validation instruments: mind maps, reflection on biography, reflection on competences, attachments, observation checklists, interview grids, validation sheets. Validpack is organised around three main validation steps: self-evaluation, external evaluation and consolidation.

Table 3. Validpack model (Adapted from: Duvekot R., \& Geerts J., 2012; IREA 2008)

\begin{tabular}{|l|l|l|}
\hline 1) SELF EVALUATION & $\begin{array}{l}\text { 2) EXTERNAL } \\
\text { EVALUATION }\end{array}$ & 3) CONSOLIDATION \\
\hline $\begin{array}{l}\text { First step (reflection of } \\
\text { biography) }\end{array}$ & $\begin{array}{l}\text { First step (observation) } \\
\text { Second step (evaluation with } \\
\text { Second step (reflection of } \\
\text { learning processes/learning } \\
\text { outcomes) }\end{array}$ & $\begin{array}{l}\text { The results have to be } \\
\text { consolidated and taken into } \\
\text { a portfolio/ validation sheet } \\
\text { Third step (reflection of } \\
\text { competences) } \\
\text { Attachment (for example } \\
\text { qualifications papers; } \\
\text { documents) }\end{array}$ \\
\hline
\end{tabular}

Key Competences for Adult Learning Professionals are also described by Research voor Beleid (2010). These are: assessment of learning needs, preparation of courses, facilitation of learning, monitoring and evaluation, counselling and guidance, programme development, financial management, human resource management, overall management, marketing and PR, administrative support, ICT-support, overarching activities.

\section{Pilot training course design}

University of Bari "Aldo Moro" (UNIBA) has developed a curriculum for the early training of all the practitioners involved in the Adult Education staff evaluation. The EduEval pilot training course has two main objectives: defining an Adult Education staff evaluator profile, with adequate specific multifunctional characteristics to operate in different contexts; and promoting the well-being, quality and productivity of all the practitioners involved in the Adult Education staff evaluation to prevent and cope with the risk of burn-out and/or other professional diseases. The training process will be focused on the main activities that are commonly required in the educational-related evaluation 
procedures. It has been designed with a combined structure and divided into didactic unities. The 30-hour course is divided in two modules: a 20-hour "in presence" module and a 10-hour "e-learning" module. The expected result is the development of knowledge (basic, specialized, and context-based ones), abilities (both general and referred to specific evaluation work processes), competences to be achieved to strengthen the professional role of Adult Education staff evaluators.

\begin{tabular}{|c|c|c|}
\hline & $\begin{array}{c}\text { Outgoing profile: } \\
\text { Adult Education staff evaluator }\end{array}$ & \\
\hline $\begin{array}{l}\text { Knowledge } \\
\text { - legislation and } \\
\text { theories in the } \\
\text { evaluation field } \\
\text { - evaluation methods } \\
\text { and tools (rubric, } \\
\text { participant observations, } \\
\text { etc.) } \\
\text { - Adult Education work } \\
\text { processes } \\
\text { - leadership styles and } \\
\text { group management } \\
\text { - emotional aspects } \\
\text { during the evaluation } \\
\text { process } \\
\text { - quality standards }\end{array}$ & $\begin{array}{l}\quad \text { Skills } \\
\text { - human resources } \\
\text { management } \\
\text { - communication } \\
\text { - group management } \\
\text { ability } \\
\text { - soft and transversal } \\
\text { skills } \\
\text { - proactive ability, } \\
\text { research attitude, } \\
\text { simulations, case studies, } \\
\text { problem solving and role } \\
\text { playing } \\
\text { - critical reflection }\end{array}$ & $\begin{array}{l}\text { Competences } \\
\text { - planning the } \\
\text { assessment process } \\
\text { according to the Adult } \\
\text { Education professional } \\
\text { field } \\
\text { - selection of } \\
\text { evaluation techniques } \\
\text { - application of the } \\
\text { evaluation tools in an } \\
\text { Adult Education } \\
\text { context } \\
\text { - information and } \\
\text { interaction } \\
\text { management } \\
\text { - staff coordination }\end{array}$ \\
\hline
\end{tabular}

Figure 1. Outgoing profile: Adult Education staff evaluator

The course is addressed to 15 participants ( 25 to 65 years), selected by each project partner in order to guarantee the heterogeneity of the professional profiles and the exchange of expertise and acquired competences within an Adult Education Organization. The course participants work as evaluators within different educational services: rehabilitation services, services for disabled people, mental health services, services for old people, intercultural integration services, inmates custody services, services for homeless people, extracurricular educational organizations (cooperatives, recreation and socialeducational centers), community centers, cultural services (libraries, cultural centers), local health corporations. Two tutorship forms are also foreseen: 1) "in presence" accompanying tutorship to be carried out by one or more referencepoint members, previously selected inside all partner teams in the different countries. The accompanying tutors should interface with the training course 
practitioners/participants. 2) e-learning online tutorship managed by UNIBA. The online tutor should interface with the accompanying tutors of the project partners. Three main instruments will be used for the course validation: a final questionnaire; assessment form to be filled at the end of each didactic unity; external judgement. The 10-hour online training activities (in the form of Learning Objects - video-lessons) are provided via a specific platform, with 2 final hours dedicated to a reflective writing module. Each video-lesson (didactic unit), except for the Introduction one, has a common structure: definition of general and specific objectives; contents; bibliographic references and links; additional documentation and wrap-up conceptual maps.

Table 4. Didactic unity 1: EduEval evaluation model

\begin{tabular}{|c|c|}
\hline Didactic Unity 1 & EduEval evaluation model \\
\hline General objectives & $\begin{array}{l}\text { Understanding the theoretical framework which EduEval training } \\
\text { refers to }\end{array}$ \\
\hline Specific objectives & $\begin{array}{l}\text { Understanding the evaluation, educational role aimed to the } \\
\text { organizational enhancement trough: internal processes analysis, } \\
\text { actions, information documentation } \\
\text { Understanding the importance of self-assessment activities for a } \\
\text { professional growth and to foster correct organizational schemes; }\end{array}$ \\
\hline Content & $\begin{array}{c}\text { EduEval evaluation model: between self-assessment, external } \\
\text { evaluation and context evaluation }\end{array}$ \\
\hline \multicolumn{2}{|c|}{ References, link, lecture notes, follow up materials, conceptual map } \\
\hline
\end{tabular}

Table 5. Educational work in the Adult Education field: indicators and competence areas

\begin{tabular}{|c|c|c|c|}
\hline INDICATORS & $\begin{array}{l}\text { Personal } \\
\text { development }\end{array}$ & $\begin{array}{l}\text { Community } \\
\text { development }\end{array}$ & Professional development \\
\hline $\begin{array}{l}\text { COMPETENCE } \\
\text { AREAS }\end{array}$ & $\begin{array}{l}\text { Self-image and } \\
\text { self-perception; } \\
\text { empowerment; } \\
\text { personal life plan, } \\
\text { personal skills and } \\
\text { competences, } \\
\text { counseling or } \\
\text { orientation } \\
\text { competences; self- } \\
\text { knowledge; mental } \\
\text { and emotional } \\
\text { well-being; } \\
\text { responsibility, } \\
\text { empathy, } \\
\text { motivation }\end{array}$ & $\begin{array}{l}\text { Democracy-based } \\
\text { culture, } \\
\text { consideration and } \\
\text { observance of } \\
\text { differences and } \\
\text { equal } \\
\text { opportunities; } \\
\text { impact of } \\
\text { individual actions } \\
\text { on the } \\
\text { community; } \\
\text { active } \\
\text { participation in } \\
\text { the community; } \\
\text { social relations, } \\
\text { inclusion }\end{array}$ & $\begin{array}{l}\text { Soft skills and crosswise } \\
\text { competences; work } \\
\text { performances; leadership } \\
\text { styles, group management, } \\
\text { attractiveness in the eyes of } \\
\text { the employees; effective } \\
\text { communication, successful } \\
\text { conflict management ability, } \\
\text { strategic identity, planning } \\
\text { abilities, systemic vision, } \\
\text { ICT skills, resource } \\
\text { management, planning } \\
\text { procedures, working } \\
\text { process documentation }\end{array}$ \\
\hline
\end{tabular}




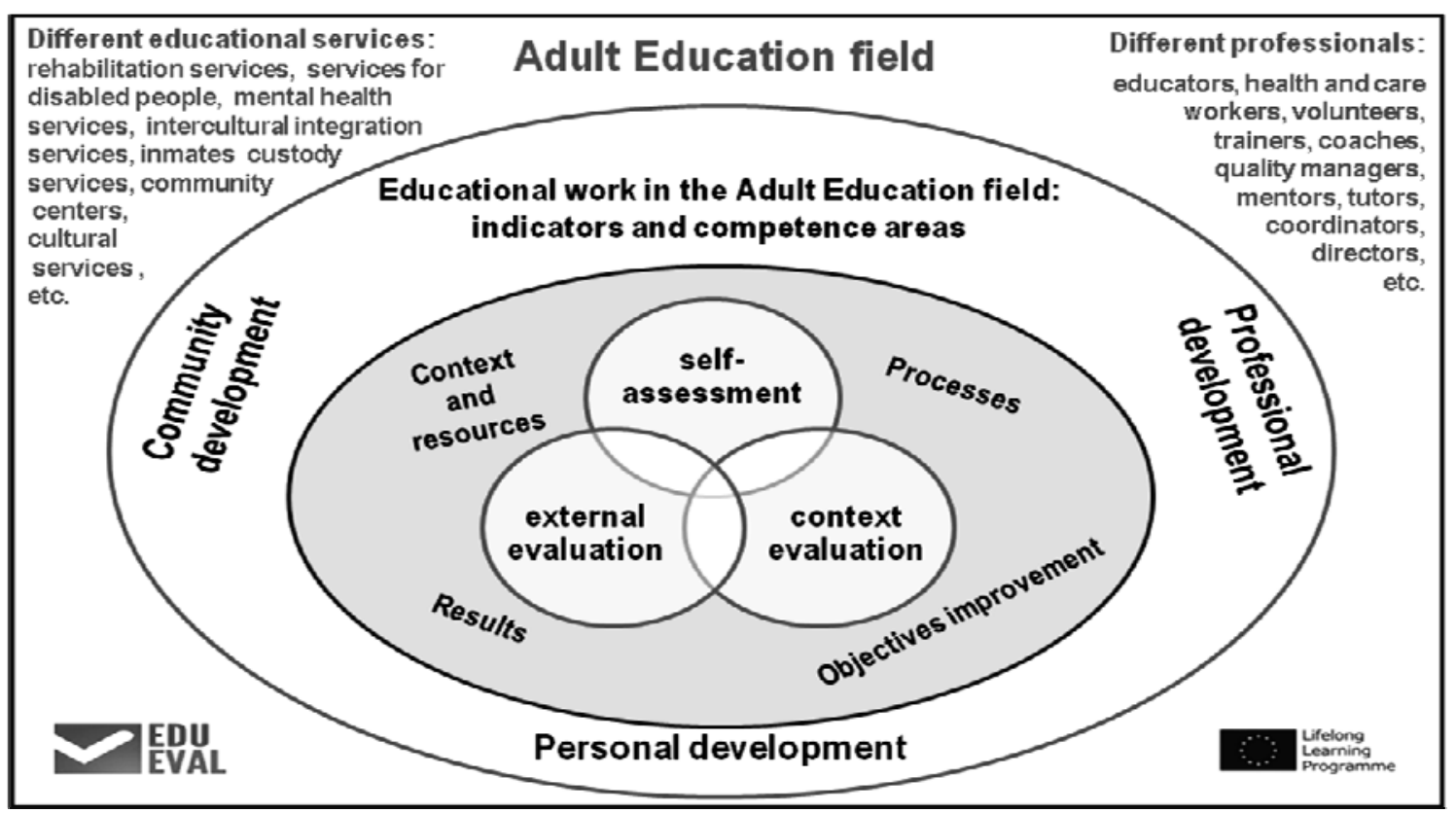

Figure 2. EduEval evaluation model

Table 6. Didactic unity 2: Evaluation methods and tools: external evaluation

\begin{tabular}{|l|l|}
\hline Didactic Unity 2 & Evaluation methods and tools: external evaluation \\
\hline $\begin{array}{l}\text { General } \\
\text { objectives }\end{array}$ & $\begin{array}{l}\text { Basic knowledge development about the main quantitative and } \\
\text { qualitative evaluation methods }\end{array}$ \\
\hline $\begin{array}{l}\text { Specific } \\
\text { objectives }\end{array}$ & $\begin{array}{l}\text { Understanding how data collection tools can be used, according to } \\
\text { EduEval evaluation purpose }\end{array}$ \\
\hline Content & $\begin{array}{l}\text { 1. External evaluation: features and practical recommendations } \\
\text { 2. Audit: advantages and disadvantages; methodological } \\
\text { suggestions }\end{array}$ \\
\hline References, link, lecture notes, follow up materials, conceptual map \\
\hline
\end{tabular}

Table 7. Didactic unity 3: Evaluation methods and tools: context evaluation

\begin{tabular}{|l|l|}
\hline Didactic Unity 3 & Evaluation methods and tools: context evaluation \\
\hline $\begin{array}{l}\text { General } \\
\text { objectives }\end{array}$ & $\begin{array}{l}\text { Basic knowledge development about the main quantitative and } \\
\text { qualitative evaluation methods }\end{array}$ \\
\hline $\begin{array}{l}\text { Specific } \\
\text { objectives }\end{array}$ & $\begin{array}{l}\text { Understanding how data collection tools can be used, according to } \\
\text { EduEval evaluation purpose }\end{array}$ \\
\hline Content & $\begin{array}{l}\text { 1. Context evaluation: features and practical recommendations } \\
\text { 2. Evaluation Rubric: advantages and disadvantages; } \\
\text { methodological suggestions }\end{array}$ \\
\hline References, link, lecture notes, follow up materials, conceptual map \\
\hline
\end{tabular}


Table 8. Didactic unity 4: Evaluation methods and tools: self-assessment

\begin{tabular}{|l|l|}
\hline Didactic Unity 4 & Evaluation methods and tools: self-assessment \\
\hline $\begin{array}{l}\text { General } \\
\text { objectives }\end{array}$ & Basic knowledge development about self-evaluation procedures \\
\hline $\begin{array}{l}\text { Specific } \\
\text { objectives }\end{array}$ & $\begin{array}{l}\text { Understanding how data collection tools can be used to promote the } \\
\text { professional and self-reflection, own practice documentation and self- } \\
\text { evaluation }\end{array}$ \\
\hline Content & $\begin{array}{l}\text { 1. Self-assessment: features and practical recommendations } \\
\text { 2. Porfolio: advantages and disadvantages; methodological } \\
\text { suggestions }\end{array}$ \\
\hline \multicolumn{2}{|l}{ References, link, lecture notes, follow up materials, conceptual map } \\
\hline
\end{tabular}

Table 9. Didactic unity 5: Context-based evaluation: steps to be taken for an evaluation visit + Self-evaluation report

\begin{tabular}{|l|l|}
\hline Didactic Unity 5 & $\begin{array}{l}\text { Context-based evaluation: steps to be taken for an evaluation visit } \\
\text { + Self-evaluation report }\end{array}$ \\
\hline $\begin{array}{l}\text { General } \\
\text { objectives }\end{array}$ & $\begin{array}{l}\text { Increasing awareness of the needed procedures to assess an Adult } \\
\text { Education context }\end{array}$ \\
\hline $\begin{array}{l}\text { Specific } \\
\text { objectives }\end{array}$ & $\begin{array}{l}\text { Developing specific steps to be taken to arrange the visit-days } \\
\text { Understanding the difference between individual and staff evaluation }\end{array}$ \\
\hline Content & $\begin{array}{l}\text { Instructions to define an evaluation rubric as the main instrument for } \\
\text { the observation inside training and educational processes, and for the } \\
\text { analysis both of professional educational styles and organizational and } \\
\text { structural context }\end{array}$ \\
\hline References, link, lecture notes, follow up materials, conceptual map \\
\hline $\begin{array}{l}\text { Self-evaluation } \\
\text { report }\end{array}$ & $\begin{array}{l}\text { Reflective writing mandatory + self-evaluation portfolio to be created } \\
\text { on the project wiki page (estimated time: } 2 \text { hours) + a assessment } \\
\text { form of the achieved contents }\end{array}$ \\
\hline
\end{tabular}

"In presence" training activities will result in two different experiences (to be chosen): workshops and internship.

Workshops: "in presence" training activities could be organised in 5 workshops (4 hour each). During each workshop, trainers will use different group running methods and strategies to promote careful reflection about one's own professional experience; case studying; professional practices' enhancement and empowerment; working context simulations. Workshops will be provided to investigate and analyse the main topics about evaluation, after each online training unit. They will be autonomously managed by the members of each partner country staff, to enhance staff competences (at this stage, no external consultants are allowed). The amount of 20 hours will be divided in no. 5 laboratories, 4 hours each.

Internship: internships will be carried out in Adult Education Organizations, to implement and try out what participants have learned during online training sessions. The amount of 20 hours will be divided in no. 2 evaluation visit-days in selected Adult Education Organizations, (8 hours each); 
no. 4 hours to share achieved experiences and for discussion between each country staff and the practitioners' group, in order to share useful notes to realize a wrap-up document. During the evaluation visits, practitioners will be followed and supported by an accompanying tutor (who will keep in contact with the online tutor). Composition of evaluation teams: 15 participants will be divided into 5 groups, ( 3 persons per group). Teams will carry out the internship in an Adult Education Organization. The external evaluation activities should be done in the selected organizations as follows: public service charter reading (or other relevant identifying documents), to have an early idea of the host organization and to write preliminary information; organizational structure observation and analysis, to fill in an evaluation rubric or a check-list; discussion and comparison among team evaluators about the acquired information and the collected data. After the 2 visit-days, evaluation and research teams will be involved in a 4-hour meeting, for a job-sharing of the achieved experiences and for discussion between each country staff and the practitioners. A wrap-up document will be drafted. In presence training activities aim to the following formative expected results:

- to start a change process inside and among the territorial organizations;

- to consider evaluation skills not only as acquired competences for a "lonely" professional, but also as a useful instrument for the organization itself;

- $\quad$ to experiment theoretical knowledge directly on one's profession;

- to guarantee the reciprocal exchange between theory and practice;

- to evaluate the online training quality and to check the full course sustainability to transfer it in other contexts;

- $\quad$ to support and integrate the individual training in a staff, introducing innovative and experimental team building procedures.

The planning of the pilot-course model, which can be confirmed through feedbacks provided by users of the Edueval project, is only the first step towards the creation of a universal curriculum that can be used in any educational \& training context with some minor change according to the specific context of use. This field has been affected by political and legislative delays involving different roles and functions which, at now, are being set right. The project and the related outcomes mean to add a contribution within the ongoing definition of the Eda staff evaluator profile.

\section{References}

Beleid, R.V., \& Plato (2008). Adult Leaning Professions in Europe, a Study on Current Situation. Zoetermeer: Research Voor Beleid.

Carlsen, A., Irons, J. (Eds.) (2003). Learning 4 Sharing: Manual for Adult Education Practitioners, Vilnius, 23-28.

Duvekot, R., \& Geerts, J. (2012). Handbook for the Assessment and Validation of Pedagogical Competences of Adults Educators. Brumar: Timisoara. 
EC (2001). Making a European Area of Lifelong Learning a Reality. COM(2001) 678 final. Retrieved from http://eur-lex.europa.eu/legalcontent/EN/TXT/PDF/?uri=CELEX:52001DC0678\& from=EN.

EC (2006). Adult learning: It is never too late to learn. COM(2006) 614 final. Retrieved from http://eur-lex.europa.eu/legalcontent/EN/TXT/PDF/?uri=CELEX:52006DC0614\&from=EN.

ECETIS project - European Competencies Evaluation Training Integrated Scheme (2011-1FR1-LEO05-24457). Core competencies and specific to the generic role of evaluator. Downloaded from http://www.adam-europe.eu/prj/9349/prd/6/2/Common\%20repertory $\% 20$ of $\% 20$ competencies.pdf

IREA (Ed.) (2008). Handbook for the use of Validpack for the validation of psychopedagogical adult-educator's competences. Brumar: Timisoara.

Jääger, T., \& Irons, J. (Eds.) (2006). Towards becoming a good adult educator. Resource book for adult educators. Retrievied from: http:/www.vabaharidus.ee/public/files/ LPIA_Agade_A4.pdf.

Jarvis, P. (Ed.) (2009). The Routledge international handbook of lifelong learning. London: Routledge.

Mathison, S. (2005). Encyclopedia of evaluation. Thousand Oaks (CA): SAGE.

Nuissl, E. (Ed.) (1999). Adult Education and Learning in Europe. Evaluation of the Adult Education Action within the Socrates Programme. Frankfurt am Main: Deutsches Institut für Erwachsenenbildung, DIE.

Nuissl E., \& Lattke, S. (Eds.) (2008). Qualifying adult learning professionals in Europe. Bielefeld: W. Bertelsmann Verlag.

Perla, L. (2004). Valutazione e qualità in Università. Roma: Carocci.

Phillips, L., Kristiansen, M., Vehviläinen, M. \& Gunnarsson, E. (2013). Knowledge and Power in Collaborative Research. A Reflexive Approach. New York: Routledge.

Research voor Beleid \& Plato (2008). ALPINE - Adult Learning Professions in Europe. A study of the current situation, trends and issues. Final report. Zoetermeer.

Research voor Beleid (2010). Key competences for adult learning professionals. Contribution to the development of a reference framework of key competences for adult learning professionals. Final report. Zoetermeer

Scriven, M. (1991). Evaluation thesaurus. Newbury Park (CA): SAGE.

Shaw, I.F., Greene, J.C. \& Mark, M.M. (2013). Handbook of evaluation: Policies, programs and practicies. London (UK): SAGE.

Weiss, C. (1998). Evaluation. Upper Saddler River (NJ): Prentice-Hall.

Yin, R. (2013). Case Study Research: Design and Methods. Fifth Edition, Thousand Oaks (CA): SAGE.

This article has been jointly developed by the authors. Loredana Perla wrote the sections Introduction, State of art; Viviana Vinci wrote the section Pilot training course design.

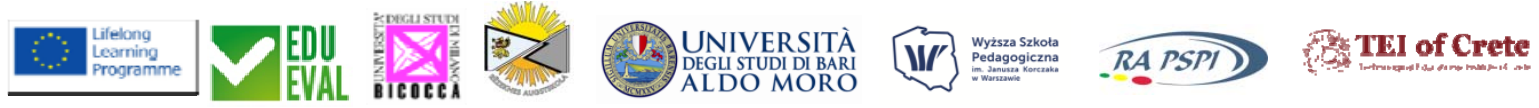

EduEval project „Evaluation for the Professional Development of Adult Education Staff'. Project Number: 538743-LLP-1-2013-IT-GRUNDTVIG-GMP. With the support of LLP Programme Grundtvig Multilateral Project. This publication only reflects the views of the Authors, and the Commission cannot be held responsible for any use which may be made of the information contained therein. 